\title{
Forskjeller og likheter mellom \\ forskningsartikkel og \\ fagartikkel
}

\section{Hva skiller en fagartikkel fra en forskningsartikkel?}

Edith Roth Gjevjon

Instituttleder og redaktør

Lovisenberg diakonale høgskole og Sykepleien Forskning

Forskningsartikkel

Fagartikkel

Akademisk skriving

Sykepleien Forskning 201914 (79023) (e-79023)

DOI: 10.4220/Sykepleienf.2019.79023

Som sykepleiere er vi forpliktet til å utøve sykepleie og helsehjelp basert på oppdatert kunnskap (1). Forskerne produserer kunnskapen, men denne kunnskapen er ikke alltid lett tilgjengelig eller klar til å bruke i praksis.

Det er et krav til forskere at vi skal publisere vitenskapelige artikler, eller forskningsartikler, i internasjonale tidsskrifter. De fleste som leser artikler i disse tidsskriftene, er også forskere, som bruker artiklene som bakgrunn for egen forskning, og som referanser i egne artikler.

Utvikling av kunnskap bygger på eksisterende kunnskap kunnskapen er kumulativ. Derfor er det viktig at forskerne skriver til andre forskere gjennom internasjonalt tilgjengelige artikler. 
Det er også viktig at kunnskapen forskerne produserer, kommer pasienter, pårørende, fagfolk og helsetjenestene til gode. Det kan gjøres på mange måter - gjennom kronikker i avisene, presentasjon av resultatene på konferanser, undervisning i utdanningen av helsepersonell og gjennom fagartikler i profesjonstidsskrifter som for eksempel Sykepleien.

\section{三 «Utvikling av kunnskap bygger på eksisterende kunnskap - kunnskapen er kumulativ.»}

Hensikten med denne artikkelen er å diskutere forskjeller og likheter mellom en forskningsartikkel og en fagartikkel. Begge typer artikler presenterer kunnskap, men på ulike måter. Hva er så de viktigste forskjellene mellom en forskningsartikkel og en fagartikkel?

Vi kan starte med artikkeltypenes hensikt. En forskningsartikkel har til hensikt å presentere ny kunnskap og beskriver på en grundig måte hvordan og hvorfor denne kunnskapen ble utviklet $(2,3)$. En fagartikkel kan ha til hensikt å gjøre ny kunnskap kjent (3) eller vise hvordan kunnskap er tatt i bruk i praksis. De skal ha praktisk eller teoretisk relevans for sykepleiefaget.

Fagartikler kan være en presentasjon av fagutviklings- eller forskningsarbeid, beskrivelse av pasientsituasjoner, trender innen arbeidsmiljø, ledelse og kvalitetsarbeid relatert til helse- og omsorgssektoren eller en bearbeidet masteroppgave om et aktuelt tema.

En helt sentral forskjell er kravet til grundighet, særlig med tanke på transparens og etterprøvbarhet. Det betyr at resultatene forskerne kom frem til, og som beskrives i forskningsartikkelen, skal kunne kontrolleres. Var metoden som ble brukt, hensiktsmessig og riktig? Viser forskerne hva de har gjort, og har de argumentert godt for hvorfor?

Forskning skal også kunne etterprøves, det vil si at andre forskere skal kunne gjenta forskningsstudien og få tilnærmet samme resultat. Fagartiklene må inneholde referanser til forskning og andre relevante kilder og dermed gjøre det klart for leseren hvilket kunnskapsgrunnlag artikkelen bygger på. 
En annen viktig forskjell er prosessen frem mot publisering. En forskningsartikkel gjennomgår fagfellevurdering, som innebærer at minst to uhildede forskere kritisk leser artikkelen og gir en grundig vurdering ut fra kjente vitenskapelige prinsipper.

En slik prosess kan ta tid, noen ganger opptil et år og kanskje lenger. Det kommer an på hvor mange runder med revisjon fagfellene og redaksjonen ber forfatterne om å gjennomføre. En fagartikkel vurderes som oftest kun av tidsskriftets redaksjon, og prosessen er relativt kort før artikkelen kan publiseres.

\section{Formatet}

Et vanlig kriterium som brukes for å skille forskningsartikler fra fagartikler, er formatet. En forskningsartikkel innen helsefaglig forskning følger som oftest IMRAD-strukturen: Introduksjon - Metode - Resultater - (and) - Diskusjon (4). Denne oppbyggingen følger forskningsprosessens faser.

Om vi ser på formatet på en fagartikkel, er det ikke like strenge regler for hvordan denne skal se ut (5). Noen fagartikler følger omtrent samme struktur som forskningsartikkelen, mens andre har en helt annen oppbygging. Ulikhetene og likhetene mellom forsknings- og fagartiklenes format diskuteres i det følgende.

\section{Introduksjon}

I en forskningsartikkel vil du finne ulike overskrifter som svarer til I i IMRAD: Introduksjon eller Bakgrunn eller Introduksjon og bakgrunn. Uavhengig av hvilke overskrifter som blir brukt, er hensikten med I-en i IMRAD å argumentere for hvorfor studien som ble gjennomført, var nødvendig å gjennomføre. Her presenteres artikkelens tematikk, «hva», og artikkelens «hvorfor» (3).

Introduksjonskapittelet avsluttes med en beskrivelse av hensikt og/eller problemstilling og/eller mål og/eller forskningsspørsmål - som forfatteren vil ha oppnådd eller besvart (2). I en fagartikkel finner vi også en introduksjon og/eller bakgrunn.

Forfatteren skal ikke argumentere for forskningen, men for bruken av forskningen samt presentere resultatene som han eller hun ønsker å gjøre kjent, eller som er bakgrunn for fagutviklingsprosjektet vedkommende presenterer. 


\section{Metode}

Metodekapittelet i en forskningsartikkel beskriver hvordan forskerne gikk frem for å produsere kunnskapen, og hvorfor akkurat denne metoden ble valgt (3). Metoden som er valgt, skal kunne besvare problemstilling og forskningsspørsmål og bidra til å oppnå hensikt og mål (2). Derfor er det viktig at metodebeskrivelsene er grundige, transparente og etterprøvbare.

I metodekapittelet skal dessuten forfatterne gjøre rede for utvalget: Hvem eller hva utgjorde grunnlaget for datamaterialet, og hvorfor? Utvalget er viktig. Hvem eller hva utvalget er, utvalgets størrelse og datasamlingsmetoden til sammen bestemmer om resultatene er gyldige ut over akkurat dette utvalget - om de er overførbare eller generaliserbare til for eksempel andre pasienter eller situasjoner (2). Her skal forfatteren også beskrive og gjøre rede for forskningsetiske problemstillinger og valg.

En fagartikkels «metodedel» kan være gjennomføringen av et fagutviklingsprosjekt eller hvordan man for eksempel tok i bruk en ny prosedyre eller et verktøy. Det er ikke krav om en metodedel i en fagartikkel, ifølge forfatterveiledningen til Sykepleien (5).

Forfatteren av en fagartikkel må imidlertid gjøre grundig rede for sine kilder, slik at leseren kan forstå hva artikkelen bygger på. Det skjer løpende i teksten gjennom henvisningene til referansene, men hvis fagartikkelen er en litteraturgjennomgang, hever det kvaliteten å beskrive søkeprosessen etter forskningsartikler i en metodedel.

\section{Resultater}

Resultatene i en forskningsartikkel er de konkrete svarene på spørsmålene forskerne har stilt. Resultatene svarer også til studiens hensikt. Resultatene skal presenteres på en nøktern måte, som hovedregel uten forskerens tolkninger (3).

Resultater fra kvantitativ og kvalitativ forskning presenteres ulikt. I artikler som omhandler kvantitative studier, benyttes oftest tabeller for å presentere tallverdier som representerer resultatene. Tekst benyttes til å lage et kort sammendrag av hovedfunnene og for kort å presentere innholdet i tabellene før tabellvisningen. 
I artikler som omhandler kvalitative studier, beskrives resultatene med tekst, og resultatene illustreres i form av sitater fra intervjuer eller beskrivelser av observasjoner. Man kan også bruke tabeller eller figurer for å presentere resultater i kvalitative studier. I resultatdelen i kvalitative artikler kan forskerens tolkninger noen ganger skinne gjennom.

Det er derfor viktig at forskeren har gjort rede for sin forforståelse, enten i metodedelen eller i diskusjonsdelen, der metoden også diskuteres. I artikler som beskriver studier som har benyttet mikset metode (mixed methods), det vil si både kvalitativ og kvantitativ metode, består resultatdelen oftest av både tall og tekst.

I en fagartikkel presenteres også resultater, dersom den for eksempel beskriver et fagutviklingsprosjekt. En litteraturgjennomgang vil ha funn og resultat i form av en presentasjon av ulike perspektiver knyttet til problemstillingen.

\section{Diskusjon}

I diskusjonsdelen av en forskningsartikkel skal leseren kunne finne ut hva resultatene betyr (3). Det er altså resultatene og diskusjonen som til sammen gir svarene på spørsmålene som stilles, og som oppfyller hensikten med studien som ble gjennomført. I diskusjonsdelen starter man med å diskutere hovedresultatene - hva som var det viktigste forskerne fant ut.

Det ble presisert tidligere at resultatene skal presenteres nøkternt og uten tolkning fra forskeren. I diskusjonen skal forskeren tolke resultatene. Hva betyr resultatene, for hva eller hvem? Forskeren skal diskutere resultatene i lys av eksisterende forskning som er relevant for tematikken og for å kunne forstå resultatene.

Forskeren kan også trekke inn sine egne erfaringer for eksempel som sykepleier. Uansett må forskeren alltid underbygge tolkninger eller fremlegging av nye argumenter eller forslag med relevante referanser - enten det er empiribasert forskning eller teorier.

\section{$\equiv$ «I diskusjonen skal forskeren tolke resultatene.»}


Diskusjonen skal avsluttes med en konklusjon - et «hva så» (3) - som beskriver hva studiens bidrag er og hvilke konsekvenser den kan ha for pasienter, pårørende, helsepersonell, helsetjenester, samfunnet, videre forskning og så videre. I en fagartikkel er diskusjonens hensikt ganske lik hensikten med forskningsartikkelens diskusjon.

I en fagartikkel bør man gjøre diskusjonen enda mer praksisnær enn i en forskningsartikkel. Her har det ingen hensikt å diskutere abstrakte begreper eller fenomener - som ofte gjøres i en forskningsartikkel.

Leserne er fagpersoner som forhåpentligvis vil ta $\mathrm{i}$ bruk kunnskapen og erfaringene som beskrives i fagartikkelen. Da er det viktig å få frem budskapet, og ikke minst overbevise leseren om nytten av fagutviklingen eller kunnskapen som beskrives i artikkelen.

\section{Oppsummering}

Denne artikkelen har til hensikt å vise forskjeller og likheter mellom forskningsartikler og fagartikler. Noen ganger kan det være vanskelig å se forskjell før man gjør en skjønnsmessig vurdering av artiklenes innhold, men det er noen klare kriterier som skiller disse typene artikler fra hverandre.

Sykepleien skiller mellom disse to typene artikler ved å publisere forskningsartikler i Sykepleien Forskning og fagartikler i Sykepleien. Noen ganger bes forfattere som $\varnothing$ nsker å publisere i Sykepleien Forskning, om heller å publisere i Sykepleien, når kravene til en forskningsartikkel ikke er oppfylt. Tabellen viser sentrale forskjeller og likheter mellom artikkeltypene.

Tabell 1. Forskjeller og likheter mellom forskningsartikkel og fagartikkel

\begin{tabular}{lll}
\hline Kriterier & Forskningsartikkel & Fagartikkel \\
\hline Fagfellevurdering & Ja & Nei \\
\hline Introduksjon/bakgrunn & Ja & Ja \\
\hline Metodebeskrivelse & Ja & Nei (men kan ha metodedel) \\
\hline Resultatbeskrivelse & Ja & Ja \\
\hline Diskusjon & Ja & Ja \\
\hline Krav til transparens og etterprøvbarhet & Ja & Nei \\
\hline Krav til pålitelig metode (reliabilitet) & Ja & Nei, men pålitelige kilder \\
\hline Krav til gyldige resultater (validitet) & Ja & Nei \\
\hline Krav til overførbarhet/generaliserbarhet & Ja & Nei \\
\hline Relevans for utøvelse av sykepleie & Ja & Ja \\
\hline Resultatene kan tas direkte i bruk i praksis & $\mathrm{Nei}$ & Ja \\
\hline
\end{tabular}




\section{Referanser}

1. Norsk Sykepleierforbund. Yrkesetiske retningslinjer for sykepleiere. Tilgjengelig fra: https://www.nsf.no/visartikkel/2193841/17102/Yrkesetiske-retningslinjer (nedlastet 02.08.2019).

2. Polit D, Beck CT. Nursing research. Generating and assessing evidence for nursing practice. 10. utg. New York:

Wolters Kluwer Health; 2017.

3. Lerdal A. Forskningsartikkel eller fagartikkel? Sykepleien. 2012;100(2):(72-73).

4. Nylenna M. Publisere og presentere. Oslo: Gyldendal Akademisk; 2015.

5. Sykepleien. Forfatterveiledning for fagutvikling: Sykepleien. Tilgjengelig fra: https://sykepleien.no/skrivfagutvikling (nedlastet 02.08.2019). 